O IMPARCIAL (editor). Araraquara, 1974 Edição da Empresa. O Imparcial Limitada. Araraquara, 1974.

PESSIS-PASTERNAK, G. Edgar Morin: contradições dos saberes. In: PESSIS-PASTERNAK G. Do caos à inteligência artificial. São Paulo: Ed da UNESP, 1993. p. 83-94.

WHITAKER, D. C. A. Araraquara: histórias não reveladas. Presidente Venceslau: Letras à Margem, 2004.

Cidade musical: Araraquara teve um grupo de cantores que marcou sua história Entrevistadora: Patrícia Piacentini. Revista Kappa, Araraquara, v. 1, n.2, n. 26, p. 68, ago. 2011.

WHITAKER, V. A.; WHITAKER, D. C. A.; SOUZA, M. F. Proposta metodológica para pesquisa de campo em assentamentos de reforma agrária. Retratos de Assentamentos, Araraquara, v. 14, n. 1, p.17-36, 201

\section{A LUPO EM ARARAQUARA: REVIVENDO A MEMÓRIA, RETECENDO A HISTÓRIA (1921 A 1980)}

Angela Cristina Ribeiro Caires ${ }^{1}$

\section{RESUMO}

Este texto é uma singela homenagem aos trabalhadores e principalmente às trabalhadoras da fábrica de Meias Lupo, atual LUPO S/A. Constitui uma tentativa de resgatar a história da empresa, por meio da memória do grupo social que trabalhou e viveu em um tempo crucial da empresa:o período que se estende de 1921, quando a empresa é fundada por Henrique Lupo, até o final dos anos 1980, quando começam a ocorrer grandes mudanças tecnológicas. Como mulher e ex-trabalhadora da empresa, valho-me também de minhas memórias e mesclo-as com as memórias de outras mulheres guerreiras para recompor uma história que na verdade são histórias. Histórias de trabalho, de lutas pela sobrevivência, de experiências concretamente vividas e que dão sentido à existência. Histórias sonhadas, muitas vezes realizadas, que insistem em voltar à memória para reviver. E estas trabalhadoras, enquanto (re) lembram, mas uma vez trabalham.

Palavras-chave: Meias Lupo S/A. LUPO S/A. Memórias de Trabalhadoras. Vida e Trabalho.

\section{ABSTRACT}

This text is a simple tribute to the workers and especially to the female workers of Lupo factory, current LUPO S/A. It is an attempt to rescue the history of the company, through the memory of the social group who worked and lived at a crucial time for the company: the period extending from 1921 when the company was founded by Henrique Lupo until the late 1980's when major technological changes have started to occur. As a woman and a former employee of the company, I also draw my memories and combine them with memories of other warrior women to recompose a story that actually are stories. Stories of work, of struggles for survival, of concrete experiences which give meaning to existence. Dreamed stories which often came true, that insist on returning to memory, to revive the past. And these Dreamed stories which often came true, that
workers, while remember, once again work.

Keywords: Lupo sockets. Lupo S/A. Female workers'memories. Life and Work 


\section{INTRODUÇÃO}

Quem chega à Araraquara, de longe avista prédio que, no alto de seus nove andares, exibe o relógio que por muito tempo marcou as horas e o ritmo da vida na cidade. Hoje, escondido entre outros edifícios construídos no centro de Araraquara, o grande relógio do prédio que antes abrigava a fábrica de Meias Lupo - e onde atualmente está instalado o Shopping Lupo continua a marcar o tempo. Tempo de trabalhar tempo de viver, tempo recordar..

Ainda me lembro de que, quando menina,
empo de viver, tempo recordar.. mesmo adolescente e já moça, da janela de meu quarto na casa da Vila Melhado, olhava as horas, controlava o tempo pelo grande relógio da fábrica de Meias Lupo. Hora de brincar, hora de ir para a escola... Depois, um pouco mais tarde, hora de trabalhar... Era o relógio da fábrica e o belo trem azul e prata, trem das $10 \mathrm{~h} 10$, que me davam o ritmo, a direção do meu viver infantil.

apito do meio dia e o locutor da Rádio em tom solene: Em Araraquara, pontualmente doze horas! A sirene instalada no alto da fábrica de Meias Lupo também está assinalando para todo o Brasil, meio dia! E continuava... A Rádio Cultura de Araraquara passa a apresentar Músicas Selecionadas, oferta de Meias Lupo.

Essas frases são lembranças, referências que guardo em coisa mudou. $\mathrm{O}$ trem, com sua beleza e imponência, deixou de passar. O apito emudeceu... Na frente do relógio, bem na frente do relógio, foi construído um edifício que obstruiu minha visão - o edifício Rosa de Prata. $\mathrm{O}$ apito do meio dia continuou por mais algum tempo, mas depois silenciou... A voz do locutor se calou. do locutor se calou... Ficaram também para trás Músicas Selecionadas que anunciavam o início d tarde na cidade.

Com 18 anos fui trabalhar na empresa. Começava ai a realizar um desejo, um sonho. Sonho, aliás, que não era so meu, mas tambem de muitas garotas de que ingressaram na fábrica ainda bem mais cedo do que eu, entre 14 e 15 anos. No meu caso isto só ocorreu mais tarde, pois alguém havia me dito, por bom tempo acreditei, que durante o período de treinamento não seria remunerada, não receberia salário, e eu precisava ganhar para ajudar no sustento da minha família.

Minha entrada como trabalhadora da fábrica de Meias Lupo deu-se no dia 02 de janeiro de 1978. Comecei ocupando a função de Auxiliar de Departamento de Pessoal. Foi uma alegria e ao mesmo tempo um susto. A lembranca dessa experiência ficou forte em minha memória. Era tempo de férias coletivas e a fábrica estava parada, escura, silenciosa... Apenas alguns ruídos, de poucos trabalhadores que se movimentavam entre os escritórios, portaria, manutenção de máquinas têxteis, segurança patrimonial, enfim os poucos setores que continuavam a se mover, não permitindo que o gigante adormecesse por completo.

E como era grande, gigantesco mesmo, quase infinito para o olhar de uma menina que acabara de chegar aos 18 anos e que vinha de uma experiência de trabalho em uma empresa bem menor. Quantas máquinas, quantos setores, departamentos fora, no pátio da fábrica e na calçada externa, na Rua Gonçalves Dias, Rua 1, uma enorme fila: homens e mulheres. Muitas mulheres: meninas, moças e senhoras mais maduras que, ansiosas, aguardavam para pegar o holerith do mês e gozar o merecido descanso depois de um ano de assustada como eu, e que acabara de conhecer, colocou em minhas mãos uma caixinha com os holeriths do pessoal em uma ordem que eu não conhecia. Junto com os holeriths uma espécie de livrinho impresso em computador - 0 índice, como era chamado. Ah, naquela época, final dos anos 1970, a empresa já usava computador, já possuía um amplo e moderno Centro de Processamento de Dados - o CPD. Aos poucos percebi que se tratava de uma relação com os nomes dos trabalhadores e trabalhadoras, com seus códigos de registro (a chapa) e os números das se comigo até a entrada da fábrica, acomodou-me em uma mesinha ali colocada e disse-me: Agora você vai entregar os holeriths para o pessoal. Orientou-me com delicadeza e saiu, retornando

Eu vinha de uma empresa que empregava Eu vinha de uma empresa que empregava
cerca de 350 trabalhadores, na qual trabalhei por aproximadamente três anos, também no Departamento de Pessoal. Conhecia cada trabalhador e trabalhadora pessoal e nominalmente: da fábrica e do escritório. Agora eram muitos, muito mais... 1200, quase 1300 pessoas - homens e mulheres. Mais mulheres, muito mais mulheres que eu começava a conhecer. Da história da fábrica conhecia pouco. Ouvira falar da sua organização, do chão que brilhava de tão limpo, das trabalhadoras que para entrar na fábrica tinham que trocar de calçado. Agora eu estava ali e podia testemunhar tudo isso pessoalmente e bem de perto. Podia ver, sentir o cheiro, compartilhar com outras pessoas aquele espaço que até então somente conseguia imaginar.

Diante do assombro e do desassossego procurei manter a calma. Aos poucos fui desenvolvendo o trabalho, aprendendo, assimilando... Não tardou para que me familiarizasse com muitos nomes: Joãos, Marias, Josés, Anas, Rosas, Roses e Rosangelas... Rostos, faces, feições... Muitos dos quais o tempo não apagou de minha memória. Alguns ainda encontro nas ruas, praças, lugares da cidade. Percebo neles as marcas do tempo de vida e de trabalho... Como eu, não são mais jovens. Gente de cantos e recantos de Araraquara: grande Vila Xavier, Carmo, São José, São Geraldo, Santa Angelina, Vila Melhado, Vila Furlan, Centro e de muitos outros bairros que naquele momento estavam se formando. Alguns vinham da vizinhanca: Américo Brasiliense, Santa Lúcia Rincão, Usina Tamoio... Gente, muita gente de carne e osso que trabalhou e viveu nos diversos setores da fábrica de Meias Lupo: Estufa, Tecer, DB/BK, Punhos, Remalhadeira, Repassadeira, Carpintaria, Oficinas, Tinturaria, Gráfica, Depósito, Escritório... Escritório... Oh! O escritório! Como era grande o escritório! Quanta gente! Que máquina barulhenta aquela da contabilidade manejada pelo Sidney, Nelsinho, Marísia... Na contabilidade ainda: Mazon, Denise, Ednéia, Ari e o João Almeida que, sob os oculos, de sua mesa, olhava tudo. No setor de custos: João Henrique, Sakae, Carlos Mori e Luiz Carlos, sempre a calcular. No Departamento de Pessoal, a Ramira sempre compenetrada a fazer cálculos e mais cálculos e a registrar tudo, minuciosamente, cuidadosamente, com sua letra bonita e diferente. A Ruthinha sempre ocupada com os trabalhos das fazendas e da parte previdenciária. Quantos trabalhadores e trabalhadoras obtiveram a sua aposentadoria pelas mãos carinhosas da Ruthinha. Jair, Leonardo, Abigail na folha de pagamento. Mais tarde outros chegaram: Maísa, Celina, Israel, Heloisa, Silvia, Wilson Pedro, Celinha, Hilário, Claudemir, Paulo, Valentim, Carlinhos, Sérgio, Dindin, Vilza, Sakae, que veio do setor de custos, e eu... Todos sob o comando do líder Basolli - nosso gerente de Recursos Humanos e do senhor Carlos Benini - gerente administrativo. E este pessoal era apenas aqueles que ocupavam o espaço em que eu trabalhava, pois o escritório, é claro, era muito mais que isto

E a fábrica que já era grande, tornou-se ainda maior. Em poucos anos assistiu a uma explosão de crescimento. Eu que circulava por seus corredores, escadas, andares achava tudo aquilo imenso, grandioso, realmente gigantesco... Em dez anos lá trabalhei, não consegui conhecer todos os seus espaços. O relógio... Ah! Até hoje recinto-me por nunca ter ido conhecer o relógio, seu mecanismo, apesar dos constantes convites do Doló, encarregado da segurança industrial. O trabalho me detinha. Entre admissões, demissões e carteiras de trabalho o tempo voava.

Chegaram os anos 1980, muita gente entrando, outros saindo... Eram homens e mulheres. Muitas mulheres: brancas, negras, baixas, altas, gordinhas e magrinhas, que chegavam para compor o quadro de trabalhadores e trabalhadoras. De aproximadamente $1200 \mathrm{em} 1978$, dez anos depois, 
eram mais ou menos 3500 entre fábrica I (Rua Gonçalves Dias), fábrica II (Rodovia Washington Luiz), Depósito Fechado (Rua Carvalho Filho), escritórios regionais, em São Paulo, Rio de Janeiro, Belo Horizonte, Recife e Porto Alegre e depósito em São Paulo.

Nos anos que viriam, no entanto, muita coisa iria mudar. A fábrica de Meias Lupo S/A, que agora já tinha alterado sua razão social e se tornado LUPO S/A, passaria por transformações ainda maiores. E um pouco desta história que pretendo contar neste trabalho. Constitui uma tentativa de resgatar parte da história dessa empresa em um tempo determinado, isto é, de sua fundação em 1921 até a década de 1980. Trata-se da história de uma empresa, mas também do grupo social: homens e mulheres que lá trabalharam e viveram. E como sujeitos que esses trabalhadores e trabalhadoras são aqui lembrados e homenageados.

Os elementos que seguem mesclam minhas memórias, como ex-trabalhadora da empresa, com pesquisas realizadas para a elaboração da minha tese de doutorado, desenvolvida na UNESP de Araraquara no período de 1994 a 1999, centrada no sistema de terceirização implantado na empresa a partir do final dos anos 1980 e início dos anos 1990 (CAIRES, 1999)

A pesquisa que se desenvolveu neste período constituiu-se de entrevistas em profundidad com antigas trabalhadoras, consultas em documentos, livros, dissertações de mestrado, jornais e revistas da época.

Evidentemente, as histórias dessa empresa desse grupo social guardam consigo uma riqueza muito maior do que foi possível apresentar no espaço limitado para esta publicação.

\section{A Fundação da}

\section{Lupo e o Fundador}

A empresa LUPO S/A foi constituída na décad de 20 do século passado. Oficialmente sua fundação data de 21 de março de 1921. Hoje, com 94 anos de existência, esta empresa registra uma história rica e importante para a cidade de Araraquara, para o estado de São Paulo, para o Brasil e para a indústria têxtil brasileira. Henrique Lupo, seu fundador, vindo de Strigno, província da Itália, chegou ao Brasil em 1888, exatamente no dia 12 de maio daquele ano e véspera da abolição da escravatura no país. Desembarcou no Porto de Santos e dirigiu-se para o interior paulista. A primeira parada foi em São Carlos, tendo seguido viagem para Araraquara, aonde chegou no dia 13 de maio de 1888. Seu pai, que no país de origem já desempenhava as funções de relojoeiro e ourives, ao chegar à cidade deu continuidade à sua profissão levando consigo o filho que, na ocasião, contava com 11 anos de idade. Assim, Henrique Lupo, tendo começado ainda muito jovem na atividade de relojoeiro e ourives dedicou-se a esta profissão durante três décadas (BRANDÃO; TELAROLLI, 1998)

A capacidade de transferir os conhecimentos obtidos nessas atividades para o manuseio de mecanismos das máquinas têxteis, tão complexos e delicados, adequando-os à produção de meias produto que também exigia muito cuidado - é uma qualidade ressaltada em sua biografia. No livro Addio Bel Campanille: a saga dos Lupo, de autoria do saudoso professor e historiador araraquarense Rodolpho Telarolli e do escritor e romancista Inácio de Loyola Brandão, também natural de Araraquara publicado em 1998 pela Global Editora, os escritores destacam esta qualidade do líder. Homem de grande carater, empreendedor, sempre esteve à frente dos negócios da família, organizando-os e dirigindo-os com habilidade.

Em 1921, na época da fundação da empresa, já se encontrava com 44 anos de idade, casado e com 9 dos 10 filhos que compunham sua prole (a última filha nasceu depois da fundação da empresa). Sen . Sem duvida as histórias da empresa e de seu fundador são simbióticas. Henrique Lupo foi o grande iniciador, construtor desta que se transformou na mais tradicional indústria da cidade e maior no ramo de confecção de meias do país. Sempre com a colaboração de seus filhos homen (as mulheres não participavam dos trabathos da fábrica) - Rômulo, Rolando, Élvio, Wilton e Aldo, que foram introduzidos na administração da empresa desde muito cedo, seja no setor comercial ou no industrial - sua atuação é destacada pela sagacidade, pioneirismo e visão de futuro com que orientava seus negócios. Foi olhando sempre para frente, perseguindo o progresso e dentro de uma ética do trabalho incansável e ascético com a qual sempre conduziu a empresa, que desde muito cedo criou uma estratégia de marketing que visou levar o nome de sua indústria e da própria família para todo o território brasileiro e também para o exterior $^{2}$. Na década de 1980, seu retrato altivo se destacava em lugar central na parede da Sala Azul (sala de reuniões localizada no andar térreo da fábrica da Rua Gonçalves Dias), espaço quase sagrado, no qual ocorriam as reuniões de cúpula da empresa, e onde as decisões importantes eram tomadas sob o olhar vigilante do patriarca e de seus filhos já falecidos ${ }^{3}$. Simbolicamente, era como se o fundador, pai e avô, estivesse sempre ali, participando, orientando, ajudando a decidir como sempre fizera em vida.

Para os trabalhadores, homens e mulheres, o Seu Henrique, como era carinhosamente lembrado, era o patrão prestimoso. Com seu terno de linho claro e bem passado, circulava pela fábrica diariamente, dirigia seus negócios de forma direta e pessoal, cuidava do que era seu, como recordam até hoje antigas trabalhadoras e antigos trabalhadores.

A história registra que, depois de ter combinado a atividade de relojoaria e ourivesaria com a fabricação de próteses por três ou quatro anos, a partir do final de 1920, a busca incessante por novos caminhos e a ampliação de horizontes levou Henrique Lupo a se interessar pela fabricação de meias. Esse interesse teria sido despertado 2 A empresa é uma das pioneiras na prática de anunciar seu produto nos campos de futebol. Esta tradição e hoje reforçada com a presença da
marca em grandes e importantes times de futebol e outros esportes que a empresa patrocina.

Nócéada de 1980, os fillos Rômulo, Rolando, Aldo e Wilton já tinha a partir de informações obtidas com viajantes, vendedores de produtos dentários que tinham certo conhecimento do setor e sugeriam-lhe as meias como atividade promissora. Assim, tendo tomado possibilidade de comprar duas máquinas de fabricar meias em São Paulo cuidou para a sua aquisição. Por meio de um representante de artigos dentários ficou sabendo da existência de algumas pequenas indústrias caseiras fabricantes de meias na cidade de Juiz de Fora-MG. Enviou seu segundo filho, na época com 17 anos, àquela cidade para receber treinamento no manejo com as máquinas têxteis e aprender sobre a produção de meias. Assim nascia a Fábrica de Meias Araraquara, depois Meias Lupo S/A e atualmente apenas Lupo S/A (BRANDÃO; TELAROLLI, 1998, p. 64-65)

Organizada inicialmente na sala de visitas da residência de seu fundador-proprietário, uma casa de aproximadamente $200 \mathrm{~m} 2$ instalada em área central da cidade (Rua 9 de Julho), a fábrica possuía então apenas duas máquinas. Todo o trabalho da produção das meias era realizado por sua própria família - esposa e filhos em idade de trabalhar. O também sob a responsabilidade da família, que se incumbiu da distribuição do produto. Em entrevista concedida à Revista Veja em 1990, Élvio Lupo, filho do fundador que esteve à frente da administração da empresa por muitos anos, declarou que, "no inicio, as vendas das meias tingidas na banheir de sua mãen foi deixar o produto em consignação para alguns comerciantes - "quatro ou cinco dúzias para cada comerciante"- com faturamento após a venda ao consumidor final. Este dado ratificado pelos autores do livro supracitado é ainda complementado com a utilizou-se também da estratégia de vendas por meio de "vendedoras avulsas", "que colocavam as meias em uma cesta de taquara e saíam oferecendo de porta em porta." (BRANDÃO; TELAROLLI, 1998, p. 69)

O sucesso deste sistema de vendas permitiu a 
aquisição de um amplo terreno que fazia fundos com sua casa - terreno de uma chácara -, no qual passou a ser erguida, a partir de 1924, a fábrica. Nesse terreno, no qual existia um pomar, a paisagem foi aos poucos se transformando. As árvores frutíferas cederam lugar a um prédio que, pouco a pouco, em lugar central da cidade de Araraquara, tornou-se grandioso e imponente. Lembro-me ainda do abieiro, que na década de 1980 era a única árvore frutífera que restou do pomar da antiga chácara. Localizado próximo à entrada do escritório, no pátio da empresa, o abieiro estava ali como símbolo dos tempos em que a fábrica era parte do quintal da casa dos patrões. Próximo a ele havia um crucifixo sob o qual estava fixada uma placa de bronze oferecida pelos trabalhadores em homenagem ao patrão e sua esposa, na qual estavam inscritos os seguintes dizeres:

\section{Não é a carne nem o sangue, e sim o coração que os faz pai e filhos (Schiller) \\ Os trabalhadores da Fábrica Lupo, qual uma grande família, prestam comovida singela homenagem a seu chefe e amigo Henrique Lupo. E com saudade estendem esta homenagem àquela que em vida foi a alma o coração desta casa, Exma. Sra. Judith Lupo -20 de março de 1954.4}

Diante do crucifixo, ao entrar para o trabalho, grande parte das trabalhadoras fazia o sinal da cruz. Eu que, diariamente, por meio da vidraça do escritório observava, um dia perguntei para uma trabalhadora a razão de tal gesto e obtive a seguinte resposta: Em primeiro lugar por respeito, e depois para enfrentar o que vem pela frente. eria-se ao árduo dia de trabalho entre muitas meias e exigências das encarregadas, ajudantes de encarregadas, e líderes de turno, que exerciam o controle no seto produtivo da empresa. Havia aqueles que diziam que na naquela tribo existiam mais caciques do que

4 A placa foi offerecida em homenagem aos 77 anos de Henrique Lupo, cuja homenagem estendeu-se também a sua esposa falecida em 19
(BRANDÃO; TELAROLLI, 1998, p. 131). índios. A obtenção da produtividade no trabalho exigia disciplina e ordem, o que por consequência requeria ampla hierarquia.

O abieiro sufocado pelo crescimento da fábrica não sobreviveu. Mesmo seco continuou ali por muito tempo. Na segunda metade os anos 1980, foi finalmente retirado e em seu lugar foi plantada uma palmeira mais resistente a ambientes fechados. A erradicação definitiva do abieiro e a sua substituição por uma planta verde e viçosa anunciava o novo momento que a empresa inaugurava. Nesse novo tempo, a realidade econômica e política do país exigia democratização das relações de trabalho, o que pressupunha um ambiente mais acolhedor e humanizado. Visava-se uma melhor qualidade de vida no trabalho.

A fábrica cresceu para lados e direções diversas: esquerda, direita, para os fundos e para cima. Aos poucos foi se transformando em um gigante ruidoso, barulhento que fascinava e assustava ao mesmo tempo. Trabalhadoras e trabalhadores que viveram essa fase ainda se recordam da construção dos prédios que foram levantados em etapas. Em 1938, quatro pavimentos já estavam prontos destacando-se como parte inseparáve da paisagem urbana de Araraquara. Brandão e Telarolli (1998, p. 111 e 126) destacam o prédio como o primeiro edifício de concreto armado da cidade "obedecendo às normas de construção dos grandes prédios da capital do Estado". O grande relógio, no apice de uma torre de nove andares, cuja conco conclusa ocorreu en 1953, foi uma homenagem ao fundador da empresa e à sua antiga profissão. $\mathrm{Na}$ torre que se ergue sobre os quatro andares onde funcionava a fábrica, apartamentos foram construídos para abrigar "dirigentes da empresa e eventuais visitantes, uma vez que Araraquara precária rede hoteleira." Na década de 1980, funcionava em alguns apartamentos parte dos setores administrativos. Na época da construção dos quatro pavimentos que abrigavam as instalações fabris (1937), as dimensões do prédio superavam a capacidade produtiva da empresa que na ocasião, dependia da importação de matéria prima - fio de algodão - da Inglaterra e Egito. A partir de 1947, a introdução de fios sintéticos na produção de meias - o Náilon - permitiu que a empresa inaugurasse uma nova era em sua história. Vanguardista na utilização do náilon como matéria prima para este tipo de produto conseguiu aumentar consideravelmente sua produção.

Na década de 1950, já apresentava significativo grau de desenvolvimento. Seu principal produto, as meias masculinas, já tinha conquistado o mercado. Começavam assim os investimentos para melhorar as meias femininas e incorporar outro segmento do mercado que vinha crescendo. $O$ náilon realmente provocou uma revolução e aquilo que era uma promessa tornou-se realidade.

Nos anos 1970, a empresa assiste a um novo salto produtivo em razão do aumento da demanda no mercado de meias, inclusive pelo fornecimento do produto para o do produto para o exército, o que faz crescer ainda mais a fábrica. Mais uma vez, o prédio começava a se tornar insuficiente. Brandão e Telarolli (1998, p. 158) oferecem perfeita descrição do que era o prédio da fábrica nos anos 1970 e 1980, realidade que também testemunhei. Faço minhas as palavras dos autores:

Se o visitante que, em 1932, entrou na fábrica ampliação e modernidade das construc̃es, ali regressosse nos and 70 [1970] ficaria assombrado. Se daquela vez, um simples portão acionado sutomaticament causou surpresa, desta vez ele se assombrari com os incontáveis corredores, divisões, puxados, mezaninos, vestíbulos, escadinhas, cubículos, resultantes da necessidade mais uma sala, saleta, escritório mostrando crescimento desordenado e improvisado.Não havia tempo de se projetar, aumentava-se aqui, fechava-se ali.

De fato, os acréscimos e arranjos improvisados eram frequentes. Sem tempo hábil para projetos, as necessárias precauções com as condições de segurança e saúde para os trabalhadores, às vezes, eram deixadas de lado. Mesmo os investimentos para oferecer condições de salubridade, com a instalação de equipamentos de ar condicionado nos escritórios ou ventiladores e umificadores de ar no espaço fabril, não resolviam completamente o problema do calor, do ruído e da poeira, desordenado que sufocou o abieiro e produziu labirintos criou um ambiente hostil no qual dia e noite se confundiam.

No final da década de 1970, não havendo mais espaço para expandir a fábrica, os empresários decidiram pela projeção de outra unidade fabril, que passou a ser construída em área pertencente a uma propriedade territorial da empresa - parte de uma fazenda - próxima a um dos distritos industriais da cidade. Para esta unidade, que começou a funcionar em 1980, foram transferidos alguns setores da fábrica: oficina mecânica, depósito e expedição. Mais tarde foi o setor de texturização (preparação dos fios), tinturaria, pré-acabamento (estufa), embalagem e tecelagem de meias colantes (na época Meias de Senhoras). A transferência desses setores abriu espaço para a reorganização dos setores produtivos, o que foi feito com o agrupamento de algumas seções, liberando espaços e tornando transferência total das atividades produtivas para esta nova unidade fabril, cuja previsão para que isso ocorresse era de cinco anos, continuava a motivar os dirigentes da empresa. Todavia, atrasos na construção do novo prédio, problemas de ordem financeira em virtude da conjuntura política e 作 possível a concretização da transernnia total no ano de 1994, momento em que a empresa já passava por reestruturação em seu processo produtivo com o uso de tecnologias modernas, de base microeletrônica e terceirização de alguns setores.

Atualmente a empresa funciona integralmente em suas novas instalações que, desde que começaram a ser construídas no final dos anos 1970, já sofreram muitas ampliações e continuam a ser ampliadas. No prédio com mais de $10.138 \mathrm{~m} 2$ de área construída, na zona central da cidade, funciona hoje um 
foi conservada, assim como o grande relógio que, altaneiro, continua a marcar as horas e a simboliza o poder desta indústria e a importância da família Lupo na cidade.

\section{A empresa e a cidade}

Na realidade, a indústria de meias cresceu e se desenvolveu com a cidade. Suas histórias estão entrecruzadas. Como unha e carne não se separam sob o risco da dor. Este entrecruzamento pode ser notado também na economia local. Além de fonte de divisas para o município, a fábrica de meias, hoje com ampla diversificação de produtos $^{5}$, exerceu e ainda exerce importância fundamental como a mais tradicional empresa da cidade e maior empregadora de mão de obra feminina local. Seu quadro funcional registra atualmente cerca de 5000 trabalhadores entre homens e mulheres - a maioria mulheres.

Como outras empresas brasileiras, viveu momentos críticos. Sobreviveu à depressão de 1929, enfrentou a crise do algodão como matéria prima no final dos anos 1950. Na década de 1960 impulsionada pela substituição do algodão pelo náilon na produção de meias, firmou-se como a única do ramo na cidade, deixando para trás a Fábrica de Meias Lia, sua concorrente na localidade. Passou a distribuir sua produção não só no mercado interno, mas também conquistou mercados estrangeiros, particularmente os Estados Unidos. Atualmente exporta seus produtos para vários países da América (BRANDÃO; TELAROLLI, 1998)

A importância dessa empresa no cenário araraquarense extrapola, contudo, o âmbito econômico. A participação na política local de membros da família fundadora, que também passaram por sua administração, é marca decisiva na história da cidade. Um de seus administradores - Rômulo Lupo, filho do fundador - dedicou-se a

5 A partir do final dos anos 1980, a empresa iniciou um processo de
diversificação da producăão incluindo inicialmente a producăo de cuecas. Nos anos seguintes, particulartente a partir dos anos $199 \%$ e 2000, passo The

política local desde a década de 1930, tendo sido eleito vereador de 1934 a 1947. Mais tarde, foi eleito e ocupou o cargo de prefeito do município por dois mandatos: de 1956 a 1959 e de 1964 1969 , governando a cidade conservadorismo. Adotou o espaço da fábrica como o lugar da política (despachava em gabinete montado dentro da empresa) e seguindo os princípios racionais com os quais dirigia a empresa, este antigo prefeito governava a cidade com "punho de aço", mantendo tudo sob o seu mais absoluto controle (BRANDÃO; TEL AROLLI, 1998, p. 140-148)

Aldo Lupo, outro filho do fundador, também dedicou-se à política. Após ser derrotado em um primeiro pleito eleitoral em 1947, foi eleito

Deputado Estadual, tendo exercido seu mandato no período de 1951 a 1954 e Deputado Federal entre 1971 a 1974. Depois de um período relativamente longo, sem participação direta de membros da família na política local, na década de 1980, outro acionista da empresa, Wilton Lupo - o nono filho do patriarca, candidatou-se a prefeito da cidade. Porém uma fatalidade tirou da disputa eleitoral (O Dr. Wilton, como era carinhosamente chamado por todos, faleceu em plena campanha política)

Paralelamente à atividade têxtil, na década 1930, a empresa passou a investir também no setor de comunicações. A PRD4 Rádio Cultura de Araraquara de sua propriedade teve concessão para funcionamento em 1934. Se em um primeiro momento funcionou com certa precariedade, em 21 de maio de 1936 foi definitivamente inaugurada.

Funcionando em prédio anexo à fábrica na Avenida Espanha, em região central de Araraquara, a rádio, sem dúvida, teve grande importância para acm hoje se encontra acima dos 50 anos certamente se lembra dos programas dominicais com concurso de música para crianças; das novenas às quartas-feiras transmitidas diretamente da Igreja de Santa Cruz; das Músicas Selecionadas, oferta de Meias Lupo, orquestradas ao meio dia, apó o apito da fábrica; do futebol da Ferroviária tardes de domingo, quando o time da Ferrinha era a sensação da cidade $^{6}$; dos noticiários nas belas vozes de locutores empolgados e enfáticos; da Irene Volpato, com sua voz suave passando receitas de bolo e outras guloseimas; do Nhô Zélio e o sertanejo raiz; do Cabo Mattiasi no plantão policia e o seu: Se você não quer virar notícia, não deixe acontecer! e quantas coisas mais... Na verdade, a emissora de rádio, que hoje está nas mãos de outro grupo empresarial (Grupo Montoro), além de proporcionar muita diversão e alegria para o povo araraquarense, foi também um importante instrumento de poder nas mãos da família Lupo Durante os mandatos do prefeito Rômulo Lupo os microfones da rádio foram abertos e serviram como instrumento para seu governo. No programa Você pergunta e o prefeito responde, levado ao ar durante a sua segunda gestão, o prefeito procurava ouvir e atender os anseios da população, construindo assim sua imagem de pai generoso, tal como fazi na fábrica (BRANDÃO; TELLAROLI, p. 148).

Nas atividades agrícolas e pecuárias, a empresa também marcou a sua atuação. Em 1939 adquiriu uma fazenda de 266 alqueires na cidade - a Fazenda Salto Grande - onde iniciou a criação de equinos, muares e suínos. Nesta fazenda, cuja sede passou a ser também o local de encontro da família, desenvolviam-se, além das atividades citadas, a cultura do café e da laranja. Nos anos seguintes, outras propriedades foram adquiridas nos municípios vizinhos de Santa Lúcia, Taquaritinga, Boa Esperança do Sul e incorporadas ao seu patrimônio. Fora do estado de São Paulo, os investimentos em terras ocorreram no município de Diamantino-MT: uma área de $7.758 \mathrm{ha}$, onde se "implantou um projeto agropecuário com incentivo da Superintendência para o Desenvolvimento da Amazônia (SUDAM)" (BRANDÃO; TELAROLLI, 1998, p. 160).

Neste conjunto de propriedades, a fazenda de Araraquara, nas imediações da cidade, representava

6 No momento em que escrevo este texto, o time da Ferroviária, depois
de 19 anos, volta a subir para a primeira divisão. A cidade e todos os de 19 anos, volta a subir para a primeira divisão. A cidade e todos o um importante mercado de trabalho para a mão de obra rural. Parte desta fazenda (12 alqueires) foi doada para a construção do Campus Universitário da UNESP - Universidade Estadual Paulista "Júlio de Mesquita Filho" de Araraquara, beneficiando as Faculdades de Ciências e Letras, Farmácia, Instituto de Química, além de uma faculdade privada de Engenharia e Agrimensura e a Escola SENAI (Serviço Nacional da Indústria). Hoje, aproveitando a infraestrutura existente e as belezas naturais, a fazenda foi transformada no Hotel Fazenda Salto Grande, local onde ocorrem eventos importantes promovidos pela empresa e pela comunidade local. Também nas imediações do Hotel Fazenda, um loteamento cedeu lugar a um condomínio fechado de alto padrão.

O MELUSA ${ }^{7}$, clube operário fundado em 1941 e construído pela empresa, com sua infraestrutura composta de piscinas, salão de festas e bailes, quadras esportivas (futebol, tênis), sala de ginástica, sauna, sala de jogos e outros equipamentos, está situado na Avenida Arcângelo Nigro (antiga Avenida Monteiro Lobato) esquina com a Rua Carvalho no centro de Araraquara. O clube sempre foi um importante espaço de sociabilidade dos trabalhadores e trabalhadoras da fábrica. Os bailes, shows, carnavais e concursos para rainhas e princesas do MELUSA são rememorados com grande saudade por antigos trabalhadores e antigas trabalhadoras. Era no MELUSA que muitos se encontravam, estabeleciam relações de amizade, namoro de posteriores casamentos. Na década de 1980, havia um considerável número de casais que trabalhavam na fábrica: marido, mulher e às vezes até filhos. Muitos se conheceram no MELUSA. Recentemente o clube passou por reformas e, renovado, continua a ser um importante ponto de encontro dos trabalhadores e trabalhadoras, porém hoje já está aberto para outros associados da comunidade araraquarense.

Com esse amplo raio de atuação, a Lupo sempre exerceu grande poder na cidade. Este poder pode ser visualizado nas diversas marcas existentes em suas 7 A Sigla MELUSA é a abreviação de MEIAS LUPO S/A 
ruas, avenidas, praças, viadutos e outros logradouros públicos que levam os nomes do fundador da empresa, de seus filhos e neto. Em local privilegiado, Praça Prefeito Camilo Gavião de Souza Neves, localizada no bairro Fonte Luminosa, encontra-se um monumento (estátua de corpo inteiro) daquele que foi, por duas gestões, prefeito de Araraquara. A Escola SENAI, no município, tem o nome de Henrique Lupo, considerado o patrono da indústria Araraquarense. Também em área cedida pelo município foi construído um bairro popular para abrigar os trabalhadores e trabalhadoras da empresa. Atualmente este bairro tem três unidades: LUPO I, II e III e de certa forma reproduz uma tradição que já vem desde os tempos em que algumas casas e sobrados foram construídos nas imediações da fábrica e do clube operário - o MELUSA - para abrigar seus trabalhadores mais graduados, especialmente pessoas ligadas à administração da empresa e mecânicos de manutenção de máquinas.

\section{A Constituiçãa do mercado de trabalho}

$\mathrm{Na}$ medida em que, impulsionada pelas vendas das meias, a fábrica crescia, mais e mais trabalhadores, principalmente mulheres, eram chamados para compor o quadro de empregados da empresa. A pesquisa realizada por Brandão e Telarolli (1998, p. 85) registra um dado que eu também, como trabalhadora do Departamento de Pessoal, tive e oportunidade de verificar, ou deja, na primira folha de paganto, totalmente seja, na primeira folha de pagamento, totalmente manuscrita, de setembro de 1924, 15 trabalhadore receberam salário, sendo 12 mulheres e 3 homens. Seguindo a tradição da indústria têxtil, as primeiras moças que se empregavam na fábrica de meias eram filhas de famílias de imigrantes que chegaram ao Brasil no início do século. Muitas dessas famílias eram conterrâneas de Henrique dessas ${ }^{8}$ Particularmente na produca 0 de meias, a

8 "As folhas de pagamento da época mostram: a maioria das empregadas 8 "As folhas de pagamento da época mostrama a aioria das empregadas trinta anos - chegou quase um ano antes de Araraquara ser elevada a Vila natural o instinto de proteç̃o em relação a seus compatriotas: ele sabia

associação do produto com a delicadeza, considerada atributo feminino, fez com que esse mercado de trabalho se caracterizasse como excelente para esse tipo de mão de obra. As mulheres sempre foram trabalho. Consideradas portadoras de qualidades como destreza, habilidade manual, delicadeza, cuidado etc. ocupavam na fábrica de meias funções ligadas ao processo produtivo, que começava com a preparação do fio, passando pela tecelagem até o acabamento. Essas tarefas, "adequadas às mutheres", dentro da estrutura ocupacional da empresa eram tidas como menos qualificadas, cabendo aos homens os trabalhos de maior status, considerados qualificados, como de mecânicos de manutenção, tintureiros, eletricistas, carpinteiros, motoristas, tipógrafos, entre outras funções com importancia fundamental, existiam também as bagueteiras, moças que bordavam meias em domicílio e em regime artesanal. Por volta do final dos anos 1950, com os investimentos da empresa em tecnologia moderna, a atividade do baguete (bordado à mão) foi incorporada às máquinas e a função de bagueteiras deixou de existir.

Saber bordar, costurar, fazer tricô, crochê era requisito importante para a admissão da mulher nos serviços da fábrica. Esta tradição atravessa os tempos e permanece ainda hoje, quando as máquinas eletrônicas já tomam conta do seu parque industrial. Desde muito cedo, a empresa procurou associar seu produto à delicadeza das mulheres e ao carinho materno. Em uma clássica propaganda produzida nos anos 1950 e veiculada em revistas e jornais de circulação nacional da época, a imagem de duas mãos femininas, finas e delicadas, confeccionando em tricô um sapatinho de lã para cổ, acompanhada da frase: Feita com mesmo carinho, sugeria esta intenção (BRANDÃO; TELAROLLI, 1998, p. 120).

$\mathrm{Na}$ fábrica, as funções exercidas pelas mulheres, sempre ligadas à produção de meias, eram: operadoras de máquinas (tecelãs da seção tecer e texturização - preparação do fio), remalhadeiras ${ }^{9}$, repassadeiras ${ }^{10}$, bordadeiras, costureiras, separadeiras de punhos, auxiliares de acabamento, mensageiras etc - trabalhos parcelares e rotineiros - podendo uma minoria alcançar posições mais elevadas como líderes de turnos, ajudantes de encarregadas, chegando no máximo à encarregada geral de seção.

A entrada dos homens na fábrica de meias deu-se inicialmente no setor de manutenção de máquinas têxteis e em trabalhos subsidiários como eletricistas, marceneiros, carpinteiros, oficina de construção de máquinas têxteis, setor gráfico etc. construção de máquinas têxteis, setor gráfico etc. Na produção de meias, propriamente dita, isto ocorreu apenas mais tarde, entre as décadas de 1960 produto e da ampliação do parque industrial com aquisição de maquinário mais moderno. Nesse momento, a e mpresa precisava trabalhar 24 horas por dia, o que tornou necessária a contratação de rapazes para o horário das $22 \mathrm{~h} 00$ as $6 \mathrm{~h} 00$, pois naquela época, a legislação trabalhista proibia o trabalho noturno para mulheres no setor industrial. A introdução dessa mão de obra, no entanto, ocorreu com certa dificuldade. A identificação da atividade com trabalho feminino afastava os rapazes e criava resistências. Assim, a passagem desses trabalhadores pela fábrica, no setor diretamente produtivo, era provisória, somente continuando por mais tempo aqueles que almejavam a função de mecânico de manutenção, posição que alguns conseguiam depois de realizar treinamento no SENAI, o que, aliás, era incentivado pela empresa.

Por esta razão, a rotatividade no trabalho pelos homens do setor diretamente produtivo era grande bem como era alto o índice de absenteísmo, de forma que a mão de obra feminina continuava a ser preferida.

\section{Aprendendo a fazer meias}

9 O trabalho da remalhadeira consistia no fechamento da ponta da meir feito com a máquina de remalhar

10 As repassadeiras eram trabalhadoras que faziam a revisão das meias, localizando defeitos.
Apesar das habilidades exigidas para a entrada neste mercado de trabalho (bordar, costurar, fazer crochê e tricô), o trabalho de confecção de meias exigia aprendizagem. No início, as moças que iniciavam nas atividades da fábrica ainda muito jovens, entre 14 17 anos e mesmo aquelas mais maduras, recebiam treinamento no próprio processo de trabalho, para o que foi contratada uma profissional especializada. Essa profissional, que veio de São Paulo, foi depois substituída por agentes de treinamento formadas no proprio cotidiano do trabalho. Trabalhadoras antigas recordam esse tempo:

Naquela época a gente entrava na fábrica. a gente entrava na rabica... agente de treinamento] ficava lá A gente já ia. $\mathrm{A}$ [nome da encarregada] da seção. Então você chegava ela te mostrava a coroa [peça da máquina de tecer meias]. Pegava, começava a enfiar um pedacinho daquele punho pra você ver. E a gente ia fazendo. Ela passava e olhava pra ver se você tinha acertado a coroa direitinho, as malhas com a agulha certa. Ali você ficava 2,3 dias. Aí você aprendia fazer aquilo, ela já ia pra outra etapa, já colocar a coroa na máquina, aquela meia leve que põe certinho ... (exoperária - entrou na fábrica em 1943)

Mais tarde, na década de 1960 , a empresa organizou um Centro de Treinamento, conhecido como Escolinha, por onde passavam todas as trabalhadoras que ocupariam funções produtivas que demandavam aprendizagem, tais como: Tecelagem, Remalhadeira e Repassadeira - funções essas que exigiam maior habilidade e destreza. Nas seções conhecidas como $\mathrm{DB} / \mathrm{BK}^{11}$ e tecelagem de punhos, onde o trabalho era mais automatizado, a inserção das trabalhadoras no processo produtivo era direta. Na década de 1980, mesmo as trabalhadoras que eram alocadas nesses setores, tinham que passar pelo Centro de Treinamento.

$\mathrm{Na}$ Escolhinha, o treinamento podia durar de um a seis meses, dependendo da dificuldade do trabalho e também da necessidade de produção 11 A seção de $\mathrm{DB} / \mathrm{BK}$ fazia parte da tecelagem de meias. Utilizava um
tipo de máquuina que não exigia transferência de punho. 
na fábrica. O objetivo desse setor era manter uma reserva de mão de obra treinada, apta a ser inserida no processo de trabalho em casos de substituição de trabalhadores demissionários, bem como, em momentos em que havia maior necessidade de mão de obra por aumento da denanda produc de obra por aumento da demanda do produto. Além de promover o treinamento profissional, a Escolinha
era ainda responsável por parte significativa do processo de socialização dos trabalhadores e trabalhadoras à cultura da empresa: seu sistema de trabalho, normas, regras, concepções... Além, é claro, das reuniões de integração e outras políticas de Recursos Humanos promotoras da socialização organizacional.

\section{O sonho do}

\section{trabalho fabril}

Entre as décadas de 1920 e 1950, a cidade de Araraquara, apesar de abrigar algumas pequenas empresas do ramo industrial, podia ainda ser considerada uma cidade predominantemente agrícola. A ausência de empreendimentos de grande porte que arregimentassem a força de trabalho urbana, particularmente a feminina, fazia da fábrica de meias uma das poucas alternativas de trabalho fabril - especialmente para as mulheres.

Desta forma, o recrutamento dessa mão de obra abundante apresentava grandes facilidades. Muitos, principalmente as mulheres, assim que alcançavam a idade ativa vinham solicitar emprego na empresa. Em Araraquara, é grande o contingente de mulheres cuja trajetória profissional é marcada pela passagem na antiga fábrica de Meias Lupo, hoje Lupo S/A. Parte significativa iniciou suas atividades profissionais na indústria e lá permaneceu até a aposentadoria.

Ao gozar do conceito de boa pagadora e oferecer alguns benefícios extras para seus trabalhadores e trabalhadoras como, por exemplo, o MELUSA Clube, havia uma atração espontânea da mão de obra, constituindo para muitas um verdadeiro sonho.

Meu sonho era trabalhar na fábrica de meias, como qualquer garota da minha idade. (antiga abalhou na fábrica na década de 1920) ${ }^{12}$

A força do sonho perpassou gerações, 60 anos mais tarde Isabel, ex-remalhadeira, falou de sua entrada na fábrica...

Todo mundo tinha $\mathrm{o}$ sonho de trabalhar $\mathrm{na}$ Lupo naquela época [década de 1980]. Eu tinha 14 anos. Então a Lupo chamou e eu fui. Na Lupo tinha o Melusa. Naquela época era um sonho. [...] Todas as meninas da minh idade, todas trabalhavam na Lupo. Com 14 anos eu entrei lá. (trabalhou na fábrica na década de 1980)

Trabalhar na fábrica de Meias Lupo era sinônimo de mudança e melhoria de vida. Garantia de carteira assinada e de obtenção de outros direitos assegurados ao trabalhador pela legislação trabalhista. Além da almejada estabilidade e de direitos garantidos, a existência do clube atu como um chamariz para esta mão de obra, tornando este mercado de trabalho ainda mais atrativo.

As moças que se empregavam na fábrica de meias, tanto no início como no passado mais recente (década de 1980), eram oriundas de famílias de trabalhadores, muitas vindas do meio rural, e viam naquele emprego uma possibilidade de mudança em seu status social, ao mesmo tempo em que poderiam ajudar no orçamento familiar.

Depois nós viemos para cá, e como a gente precisava, era pobre, só meu pai que trabalhava e a gente tinha aquele sonho de trabalhar numa fábrica, aquela coisa... Eu sempre fui, de casa, a mais saidinha. Então meu sonho era trabalhar assim, numa fábrica. Então eu fui lá, pus a cara. Fui lá na fábrica, fiz a minha ficha e ..." (Ex-operária. Entrou na fábrica em 1952 e percorreu longa trajetória no interior da empresa, tendo chegado a ocupar o cargo de encarregada geral de seção) 12 Depoimento de uma antiga trabalhadora colhido por Brandão e
Telarolli $(1998, \mathrm{p} .72)$
O trabalho fabril representava também a busca das mulheres por melhores oportunidades de trabalho e de vida. A atração que este mercado de trabalho exercia e a facilidade em arregimentar essa força de trabalho, visto que as oportunidades de emprego feminino na cidade eram reduzidas, permitiram que a empresa, desde as décadas de 1940 e 1950 , promovesse um rigoroso e racional processo de seleção de pessoal que privilegiava as trabalhadoras brancas, solteiras e alfabetizadas. Para serem admitidas na fábrica as candidatas a emprego passavam por uma bateria de testes que media principalmente: controle motor, agilidade e destreza, conforme revela o depoimento que segue:

A gente passava por um exame de... Você tinha que manipular... Eu não vou lembrar. Era a [nome da funcionária do Departamento de Pessoal] e o seu [nome do chefe do Departamento de Pessoal] que fazia. Você tinha que fazer quadradinhos, você tinha que fazer círculos, você tinha que pegar pedrinhas com a mão direita, depois com a mão esquerda pra ver a sua habilidade, sua esperteza nas mãos. Eram vários testes. Não tenho certeza se eram seis ou oito testes. ( ex- Operadora de Máquinas Tecer - trabalhou na empresa na década de 1950)

Esse sistema de contratação e absorção da mão de obra teve eficácia até final dos anos 1970. No anos 1980, a demanda crescente por mão de obra em uma cidade que já não tinha mais as características dos anos 1940 e 1950 exigiu novos procedimentos por parte da empresa. Nessa época, todos, independente de raça ou cor, estado civil, são chamados a compor a força de trabalho na empresa. Mas, o fato de, em tempos anteriores, não contratar trabalhadores negros ficou como uma marca negativa em sua história.

Os negros começaram a entrar na fabrica depois que o seu Rômulo foi candidato, que acho que surgiu este problema. Que a fábrica não admitia pessoas de cor. Aí começou a aparecer. Mas antes não tinha. [...] Acho que desde a primeira eleição que ele ganhou já começou a entã gête negra. [...] (ex. década de 1940)

Ainda que tivessem começado a ser admitidos nos trabalhos da fábrica na década de 1960 provavelmente por questões políticas, o fato é que até o final dos anos 1970 o número de negros trabalhando na empresa era ainda bastante reduzido. Poucos, muito poucos podiam ser vistos no setor fabril apenas. Na década de 1980 , porém, com o crescimento da fábrica, maio demanda no mercado de meias e a necessidade crescente de mão de obra é que se observa maior presença de negros nas atividades da empresa. Mas esta presença ainda fica reduzida ao setor fabril. Nos setores administrativos o emprego desta mão de obra era praticamente inexistente, dois ou três trabalhadores apenas.

A alfabetização das operárias era outra exigência neste mercado de trabalho. Embora exercessem um trabalho considerado não qualificado, pois executavam tarefas repetitivas, a alfabetização primária era exigida. Isto se tornava mais um fator de exclusão, em uma época em que os níveis de analfabetismo no país, sobretudo entre as mulheres, eram altos. Uma trabalhadora que trabalhou na fábrica na década de 1950 se lembra de que:

Naquela época pra entrar lá [na fábrica] vocè tinha que ter uma carta de um professor, ou você tinha que ter o diploma primário, $\mathrm{e}$ eu não tinha. O SESI (Serviço Social da Indústria) dava um curso popular no prédio da Rádio Cultura, e eu tinha diploma: CP 1 e CP 2 [Curso Popular] e eu fiz esse curso, o CP 1 e o CP 2 que era o Lupo que subsidiava esse curso. Então era um curso de costura, que o SESI... [oferecia] Mas era o Lupo que pagava né. E eu fiz. Então quando eu entrei lá, eu apresentei o diploma do curso popular. (ex-operadora de máquinas) 
Ao se constituir como empresa familiar, para a admissão na fábrica, contava também a indicação de parentes e amigos que já trabalhavam na empresa.

Naquele tempo era fácil entrar na fábrica. Eu tinha minha irmã que trabalhava no escritório e tinha a [nome de outra irmã] que trabalhava na remalhadeira. Então quando a candidata. Se tivesse... A fábrica, no começo, perguntav se tinha um parente... Então era tudo um meio mais familiar, sabe? Então você indicava uma prima... Muitos lugares eles não querem saber de parente, de irmão, de nada né? Então esse processo sabe? Então era assim mais uma família. Nossa! Eu conheço gente que tinha.. As [nome] tinha 4 ou 5 irmãos na fábrica. Eu mesmo tive 4. Outra minha irmã também trabalhou. Nós somos em 4 irmãos que trabalharam na fábrica. Sempre teve família que todos passaram por lá, sabe? Tinha aquele vínculo de amizade né (Encarregada de seto - trabalhou na empresa desde 1943)

A prática de contratação de parentes, amplamente utilizada pelos empresários da época, e que prevaleceu na empresa com pequenas alterações até a década de $1980^{13}$, implicava em um maior comprometimento dos trabalhadores com a empresa assegurando trabalho ordeiro e disciplinado. ${ }^{14}$

\section{O bom patrão: construindo
a moral do trabalho}

Paternalismo combinado com rigidez marca a história desta indústria. Desde o seu início, o fundador e depois os seus sucessores procuraram criar um sistema de trabalho que incluía concessões que buscavam aproximar trabalhadores e empresa, criando um clima de

13 Até a década de 1980 eram exigidas cartas de apresentação para todos (4) candidatos (as) a emprego.

14 Na década de 1980 , todo candidato ou candidata a emprego tinha sua ficha passada por verificacąa pela delegacia de policia para tentar admissão na empresa: possuir 14 anos de idade, ter bons antecedentes (não constar na lista de elementos indesejáveis à empresa - caderno azu)

estar em dia com o serviço militar em caso de trabalhadores do se

cordialidade entre patrões e empregados.

Exemplo disso foram as caravanas para Santos, cidade do litoral paulista, realizadas a partir de 1938. Esta viagem, oferecida aos trabalhadores e trabalhadoras mais eficientes como um premio pela dedicação ao trabalho, é relembrada como parte de um tempo glamouroso da empresa.

\begin{abstract}
Naquele tempo o jeito de trabalhar era diferente. Se você era assim uma pessoa que tinha vontade, uma pessoa que com o tempo adquiria aquela capacidade, tudo, que tinha uma produção por mês, se você conseguia dar aquela produção por mês, quando chegavam as férias você tinha direito $\mathrm{a}$ ir pra Santos. Viagem pra Santos eles davam, com direito a tudo. A fábrica pagava tudo. Se você desse aquela produção. E não era assim... Era uma produção que dava pra gente trabalhar tranquila assim. [...] E a gente recebia todos os direitos assim, tudo bem. A fábrica não era assim qualquer coisinha... (Encarregada 1950 até início dos anos 1980)
de sẽcada de
\end{abstract}

As férias naquela ocasião ocorriam entre os meses de abril e maio. Aproveitando a baixa temporada nas praias paulistas, a empresa oferecia a viagem para seus trabahadores, como a possibilidade de realização de um sonho que os salários não podiam pagar. A ida antecipada de uma equipe da empresa para Santos garantia uma programação ampla e animada, que fazia da temporada de permanência na praia algo inesquecível. Essa experiência vivenciada pelas trabalhadoras e trabalhadores guardada em suas memórias, é rememorada como um momento de grande alegria que marcava um hiato temporal entre o mundo do trabalho em Araraquara e um mundo diferente, em que as águas salgadas de Santos e o glamour dos hotéis faziam revigorar as forças para mais um ano de trabalho dedicado.

A gente ficava no Palace Hotel! Ah!!! A gente que nunca tinha saído de casa!!! Nem 政 uma escada, duas escadas, uma por aqui, outra por aqui [mostra a disposição das escadas na frente do hotel] Nossa!!! Pra gente era coisa do outro mundo. Sobremesa era Romeu Julieta (ri). A gente nem... Que sobremesa quê? Pobre nem tinha sobremesa. Salsicha... Menna!.! Ningún Tinha aqui no centro da cida me, mas Tinha aqui no centro da cidade, mas não encia essas coisas. A gente conprava en ñ̃o tin. negícios. Eñ̃ a gente ño conhecia Eu fui nas lojas Americanas, levei 17, não sei se era mil reis, o que er. Eu fui nas lojas American pacia paráso. Tudo aqueles brinquinos, aques colarzinos... Gastei todo o dishe (ii). Fiquei sem um tostão. Não tinh dinheiro nen pra comprar um sorvete. Das outras vezes Mas também o dinheiro era tão pouco. Se você comprasse uma pipoca, vocêtinh que guardar o dinheiro pra comprar um sorvete. Você pensa que Araraquara era como hoje? (1998). Mas era bom. Você saía de Santos às 8 horas da manhã Vinha de trem, era de trem a viagem. Saía às 8 horas da manhã $O$ hotel pegava a gente. Então eles davam cachorro quente. Então já comia ali e depois vinha até Araraquara sem comer nada, porque não tinha dinheiro pra comprar lanche. A gente gastava tudo né. Já levava pouco e ainda gastava tudo no que via.(Encarregada de Seção - entrou na fábrica em 1943)

As viagens para Santos, de fato, ofereciam às trabalhadoras e trabalhadores a oportunidade de experimentar uma realidade, um estilo de vida totalmente diferente do vivido em uma cidade interiorana. Permitiam adquirir novas experiências. $\mathrm{Na}$ verdade, era como se, de repente, passassem para um mundo novo, repleto de novidades e pouco acessível principalmente às mulheres trabalhadoras. Nesses momentos os laços entre patrões e empregados eram estreitados. A presença dos patrões nas caravanas e sua participação efetiva nos momentos de lazer dos trabalhadores atualizava a ideologia da empresa como uma grande família.
A viagem para Santos atuava como um importante estímulo para o trabalho. Os depoimentos das trabalhadoras mais antigas marcam esse tempo como um tempo bom, em que o árduo trabalho na fábrica era compensado por momentos de grande euforia e prazer. $\mathrm{O}$ prêmio, por elas bem recebido, garantia a alegria que compensava o trabalho ordeiro e disciplinado do ano todo.

Era o prêmio. Era o tempo do seu Rômulo. Seu Rômulo!!! Então ele era assim: Ele er um homem enérgico, ele não queria vocề brincando em serviço. Tinha que ficar lá quietinha, trabalhando... Ele não queria conversa... Ele passava todo dia assim, dando uma olhadinha por cima. [faz com a cabeça como o patrão exercia a vigilância sobre as como o patrão exercia a vigilância sobre as
trabalhadoras] Se ele visse num papinho, mandava passar na salinha dele. Ele chamava a atenção. Quer dizer, não que ele desse aquela bronca. Conversava com a gente. Quer dizer, todo mundo tinha medo do seu Rômulo.. Mas era assim, o prêmio dele era isso aí [a viagem para Santos]. Então ele queria que trabalhasse direitinho, desse produção... O prêmio era o passeio prá Santos. (ex-encarregada de seção)

As viagens para Santos, rememoradas como experiências vividas e sentidas em um tempo bom, são ainda descritas pelas antigas trabalhadoras como o momento do descanso, do luxo, das novidades que elas não podiam usufruir em suas próprias casas.

Era gostoso! Era gostoso! No começo a gente ficava em pensão. Depois teve uma época que nós ficávamos no hotel Martini, era hotel, era um prédio grande. Nossa!!! A gente se sentia uma filhinha de papai, como uma ricaça. Você só dormia e comia. Tudo, apartamento com telefone, tudo. Então a gente escolhia. Por exemplo: você era minha amiga, podia ficar 3 ou 4 no quarto. A gente combinava: vai ficar eu, fulano, fulano... Era a coisa mais gostosa!!! A gente saía dar os passeios... Não gostosa!!! A gente saia dar os passeios... Não
precisava nem sair muito. Só em frente do hotel, a gente sentava lá. O pessoal lá em Santos já sabia que a Caravana já vinha, então a lá bater papo. A gente sentava lá em frente, 
ficava batendo papo... A noite tinha bailinho lá também sabe? Tinha um salão pra festa, ficava os bailinhos a noite... Então era assim. Era otimo, era uma beleza. E também várias vezes..., O tempo do Dr. Witon tambén. Ná "lesso deixar de falar do Dr. Wilton que era "legal a bessa" sabe? Acertava assim pra gente conhecer navios, navios estrangeiros, Eente pra São Paulo, pra televisão. Leva gente pra São Paulo, pra televisão... Fazia lá propagana de... Levava a gente na TV tem hoje de auditório, entrograna lá como uma turminh Quem unia era eses cisings a gente fosse vir a gente mesmo ño podia A gente fuse tablla em que dor o dinheirinho emc cara, no dinheiro pra ficar castando assim. $E$ ise tem uma coisa que vinha do céu pra. Eente. Você tinh . Você levantava, tomava café, che... Voce levantava, tomava cafe, sáh, Você não tinhe aquela preocupac̃o que ne. tem em casa. Você tirar a mesa.. Lá não, era vidinha de rico. $\mathrm{E}$ as refeições eram boas, refeições muito boas mesmo. Sobremesas boas escolhia a sobremesa ainda. Foi uma

Essas viagens que se estendiam inclusive para os familiares dos trabalhadores e trabalhadoras, cujos pais poderiam participar da caravana sob a condição de custearem suas despesas, constituíam de fato um grande acontecimento que extrapolava o âmbito grat. Noticiad local. Notici: meios de comunicação da época, esta prática era destacada como pioneirismo e vanguardismo dos empresários, que se antecipavam a mais moderna legislação social (BRANDÃO; TELAROLLI, 1998, p. 114-115)

Ignorar o aspecto ideológico dessa concessão e dos reflexos que isto tinha para o aumento da produtividade do trabalho, e consequente acumulação de capital para os empresários, é cair numa armadilha ingênua, desconsiderando as contradições presentes no sistema capitalista. Mas, por outro lado, é preciso pensar nos significados propriamente humanos da viagem. Neste sentido cabe citar o filósofo brasileiro Sérgio Paulo Rouanet,

quando anota que: "Só os homens viajam, pois os animais limitam-se a migrar, como os salmões e as gaivotas, para a desova ou fugindo dos rigores do inverno; só os viajantes são inteiramente humanos." (ROUANET, 1993, p. 7)

O filósofo alerta que a viagem revela o desejo, a esperança do novo. Viajar significa sempre ir atrás de novas aprendizagens em que o momento da chegada supere o da partida. Quando se manifesta o desejo, o sonho deixa-se para trás o trânsito e tem-se finalmente um homem ou uma mulher transormado. Viajar é preciso como uma necessidade humana. O homem só se tornou homem quando saiu do seu lugar. A viagem permite o contato com a diversidade. Portanto, viajar é um ato de liberdade e não de prisão (ROUANET, 1993, p. 7).

sso pode explicar a aceitação das viagens para Santos pelas trabalhadoras e trabalhadores, que guardam na memória essa boa lembrança. As caravanas para Santos aconteceram até o final da década de 1960. Nos anos 1970 começam a mudar. Nesse processo, inicialmente a fábrica deixa de custear totalmente as viagens, passando a cobrar uma parte dos trabalhadores. Depois, aos poucos, vai cortando esse benefício, oferecendo apenas a colônia de férias da Federação dos Trabalhadores nas Indústrias de Fiação e Tecelagem do Estado de São Paulo, localizada na Cidade Ocian, na Praia Grande - litoral paulista. A colônia de férias deixou de ser um grande atrativo. O pagamento de uma taxa para ocupação dos pequenos apartamentos, que ofereciam apenas estadia, não incluindo nenhuma despesa com alimentação e transporte, tornava a viagem muito cara para trabalhadoras e trabalhadores de poucos recursos, implicando numa poupança durante o ano, o que poucos conseguiam. Além disso, a disputa para conseguir um apartamento na época das férias, que passou a ser em dezembro, período de alta temporada, era muito grande. Aluta para conseguir um apartamento no final do ano começava entre os meses de março e abril. Apesar da lista de reserva, apenas poucos trabalhadores e trabalhadoras em um processo de seleção que procurava oferecer oportunidades para aqueles que ainda não haviam viajado neste novo sistema.

Além da viagem para Santos, outros equipamentos faziam parte da política de trabalho da empresa. Desde muito cedo, no conjunto de benefícios que oferecia pode-se destacar a assistência médica ambulatorial com o fornecimento de medicamentos básicos mantidos pelo ambulatório, que visava oferecer um tratamento curativo imediato. Este serviço, que a princípio comportava apenas a contratação de um médico com especialidade em clínica geral, contemplava favoravelmente os trabalhadores e trabalhadoras do período diurno. Aqueles que trabalhavam no turno da noite, quando acometidos por alguma doença durante o horário de trabalho, eram encaminhados para o Pronto Socorro ou Santa Casa de Misericórdia de Araraquara, hospital com o qual a empresa mantinha convênio. Se desejassem ser atendidos pelo médico da empresa tinham que marcar consulta com antecedência, o que não resolvia os problemas imediatos. Somente na década de 1980, o oferecimento destes serviços foi ampliado com a contratação de mais um clínico geral, um ginecologista e um pediatra para atendimento dos trabalhadores e de seus filhos. Ainda na área médica, a manutenção de convênio com uma Cooperativa de Serviços Médicos e Hospitalares - A UNIMED - complementava o atendimento médico/hospitalar dos trabalhadores e trabalhadoras. Da UNIMED, contudo, não eram todos que participavam, mas apenas aqueles que optavam pelo pagamento deste benefício. Mais tarde, já na segunda metade dos anos 1980, houve ainda a inclusão de novos planos de saúde que procuravam beneficiar os empregados do staff superior: superintendentes, gerentes, chefias.

Também a assistência odontológica era oferecida aos trabalhadores por meio de convênio mantido com o SESI. Este convênio que atendia um número reduzido de pessoas funcionou efetivamente até o início dos anos 1980. A partir de 1984 ou 1985, mais ou menos, foi cortado, passando a ser realizados convênios com profissionais do mercado. Nesta nova modalidade de convênio, a fábrica não mais se responsabiliza pelo pagamento das despesas, mas apenas facilita o encaminhamento e atendimento, apresentando, por meio de carta, o trabalhador ao profissional escolhido e efetuan das parcelas em folha de pagamento. O mesmo procedimento é usado com os convênios mantidos com farmácias.

No lazer, a busca de um trabalho sadio ligado à prática do esporte, foi estimulada com a construção do clube operário já mencionado - o MELUSA Clube. Este equipamento exerceu um papel muito importante no conjunto de concessões oferecidas pela empresa, representando, como citado, um chamariz para a força de trabalho.

Ainda na área social, festas e jantares eram oferecidas ao pessoal dos setores administrativos, com relativa frequência. No final da década de 1970 até início dos anos 1980, eram comuns as pizzadas ofertadas para os trabalhadores dos setores de depósito e expedição de meias e escritórios, quando o faturamento da empresa superava o esperado. As reais responsáveis pela produção - as operárias no entanto, ficavam de fora destas comemorações. A partir de meados dos anos 1980, os jantares, pizzadas e outras festas foram substituídas pela grande festa de $1^{\circ}$. de Maio, realizada na fazenda Salto Grande, e que reunia todos os trabalhadores, inclusive seus familiares.

$\mathrm{O}$ presente de casamento era outra prática comum na empresa. No início, quando esta estimulava as moças que se casavam a deixar o emprego, era-lhes oferecida uma bonificação que, muitas vezes, garantia a compra do enxoval. Com a mudança na política de Recursos Humanos da empresa, e a permissão para que as trabalhadoras continuassem no emprego depois do casamento esse procedimento mudou.

O presente de meias, mais um item no conjunto de benefícios sociais que a empresa oferecia consistia no oferecimento de alguns pares de meias para os trabalhadores quando o inverno se aproximava. Na segunda metade da década de 1980 
do trabalhador ou da trabalhadora.

A concessão de casas para os empregados que ocupavam posições estratégicas na hierarquia da empresa, com pagamento de aluguel simbólico, foi também elemento importante no conjunto de benesses oferecidas pela empresa. $\mathrm{Na}$ década de 1980, com as mudanças nas relações de trabalho ligadas ao processo de racionalização que a empres atravessava, estas casas deixaram de ser cedidas para esses trabalhadores que passaram a paga aluguel para permanecer morando nelas, ou tiveram que se mudar.

Aos poucos, e na medida em que a lutas políticas dos trabalhadores brasileiros avançavam rumo à conquista de direitos, especialmente na década de 1980, a fábrica incorporava mais alguns benefícios. Exemplo disso foi o oferecimento de um desjejum mais completo que deixou de ser apenas cafe com leite e incluiu também um pão francês com manteiga. Este oferecimento visava criar condiçõe para um trabalho vigoroso, visto que muitos trabalhadores e trabalhadoras saiam muito cedo de casa para o trabalho, e boa parte deles sequer tinha condições de se alimentar em suas casas.

A creche, organizada na década de 1980 para abrigar os filhos das trabalhadoras até completarem um ano e meio, foi uma conquista por suas reivindicações e garantiu o cumprimento de uma exigência da fiscalização trabalhista.

O conjunto de benefícios gerava gratidão fidelidade e respeito à empresa. O bom acolhimento dos trabalhadores da fábrica de Meias Lupo na cidade e no comércio local Meias Lupo na cidade e no comércio local da empresa como a segunda casa e dos patrões como pais generosos, por muito tempo inibiu a formação de uma consciência crítica capaz de Mas não impediu que ações e manifestacos. de resistências de resistências se manifestassem no cotidiano do trabalho e mais tarde, na década de 1990 resultassem na formação de um sindicato - o Sindicato dos Trabalhadores nas Indústrias Têxteis de Araraquara.
Este fato por sua importância fundamental, pelo seu significado, bem como todas as mudanças verificadas a partir dos anos 1990, marca a inauguração de um novo momento na história resa e do grupo social cons seus trabalhadores e trabalhadoras e de Araraquara. Mas este, como afirmado, é outro momento. Momento marcado por rupturas e continuidades, cuja claridade somente pode ser alcançada a partir da história aqui registrada.

A história do grupo social constituído pelos trabalhadores e principalmente pelas trabalhadoras da Fábrica de Meias Lupo, atual LUPO S/A, é sem dúvida uma história de trabalho, mas acima de tudo uma história de vida. Vida que mescla momentos de alegrias, mas também de muita luta. Luta para garantir a sobrevivência, e muitas vezes, mesmo

\section{REFERÊNCIAS}

BRANDÃO, Inácio de Loyola; TELAROLLI, Rodolpho. Addio Bel Campanile: a saga dos Lupo. São Paulo: Global, 1998

CAIRES, Ângela Cristina Ribeiro. Fios Tecidos: a malha da terceirização no setor têxtil em Araraquara. $380 \mathrm{f}$ Tese (Doutorado em Sociologia). Universidade Estadual Paulista "Júlio de Mesquita Fillo"-Faculdade de Cienncias e Letras - UNESP, Araraquara, 1999

ROUANET, Sérgio Paulo. A Razão Nômade: Walter Benjamim e outros viajantes. Rio de Janeiro Editora UFRJ, 1993

\section{USINA TAMOIO: LUGAR DE TRABALHO E DE VIDA}

Angela Cristina Ribeiro Caires ${ }^{1}$

\section{RESUMO}

Este texto resgata a história da Usina Tamoio e do grupo social constituído por seus trabalhadores e moradores, no período de 1917 a 1969. Antes de mais nada, é uma história de homens, mulheres e crianças que lá moraram, trabalharam e viveram. Mais do que o resgate da história da empresa, procura recontar, por meio das próprias vozes dos sujeitos, de suas vivências, experiências e memórias uma história de vida e de trabalho. História que ficou marcada no corpo e na alma dessa gente trabalhadora que fez da Usina Tamoio um importante patrimônio de Araraquara.

Palavras-chave: Usina Tamoio. História. Trabalho e Vida.

\section{ABSTRACT}

This text recalls the history of Tamoio Mill and of the social group made up of their workers and residents in the period from 1917 to 1969. First of all, it is a story of men, women and children who worked and lived there. More than the rescue of the history of the company, it tries to retell, in the subjects' voice, their experiences and memories, a story of life and work. A story that was marked in body and soul of these hard-working people who made the Tamoio Mill an important legacy to Araraquara. 